\title{
Analysis of cardiovascular risks in practitioners of unsupervised exercises
}

\author{
Análise dos riscos cardiovasculares em indivíduos \\ praticantes de exercício físico não supervisionado
}

\section{Renata Cristina Oliveira Penha ${ }^{[a]}$, Danielle Silva Yamamoto ${ }^{[\mathrm{b}]}$, Isabel Aparecida Porcatti de Walsh ${ }^{[\mathrm{c}]}$, Gualberto Ruas $^{[\mathrm{d}]}$, Marilita Falangola Accioly ${ }^{[\mathrm{e}]}$}

[a] Graduate, Universidade Federal do Triângulo Mineiro, Uberaba, MG - Brasil. e-mail: renata.uftm@gmail.com

[b] Graduate, Universidade Federal do Triângulo Mineiro, Uberaba, MG - Brasil. e-mail: danielle-sy@hotmail.com

[c] PhD, professor, Universidade Federal do Triângulo Mineiro, Departamento de Fisioterapia Aplicada, Uberaba, MG - Brasil, e-mail: ewalsh@terra.com.br

[d] PhD, professor, Universidade Federal do Triângulo Mineiro, Departamento de Fisioterapia Aplicada, Uberaba, MG - Brasil, e-mail: gualbertoruas@yahoo.com.br

[e] PhD, professor, Universidade Federal do Triângulo Mineiro, Departamento de Fisioterapia Aplicada, Uberaba, MG - Brasil, e-mail: marilita@terra.com.br

\section{Abstract}

Introduction: Physical exercise is recommended by health professionals for the prevention of cardiovascular events; for it is important that practitioners follow recommendations of qualified professionals. Objectives: To analyze the cardiovascular risks and the physical exercise of regulars of a municipal public park. Materials and methods: 110 regulars of a municipal public park were evaluated by questionnaire and physical examination, 60 men and 50 women with a mean age of $48.8 \pm 11.76$ years. Cardiovascular risk was classified according to the American Table and physical activity following the recommendations of the American College of Sports Medicine and the American Heart Association. Results: Regarding the classification of cardiovascular risk, 54\% of the studied population presented potential risk and 31\% moderate. As for physical exercise, $58 \%$ were considered inactive, $14 \%$ active and $28 \%$ were very active. $90 \%$ received 
no professional guidelines. Conclusion: The public park goers have cardiovascular risk and do exercise without individualized guidance.

Keywords: Risk factors. Cardiovascular diseases. Physical activity. Walking.

\section{Resumo}

Introdução: A prática de exercícios físicos é preconizada pelos profissionais da saúde para a prevenção de eventos cardiovasculares; para tal é importante que os praticantes sigam recomendações de profissionais qualificados. Objetivos: Analisar os riscos cardiovasculares e a prática do exercício físico dos frequentadores de um parque público municipal. Materiais e métodos: Foram avaliados por meio de questionário e exame físico, 110 frequentadores de um parque público municipal, sendo 60 homens e 50 mulheres com idade média de 48,8 \pm 11,76 anos. $O$ risco cardiovascular foi classificado de acordo com a Tabela Americana e a atividade física seguindo as recomendações da American College of Sports Medicine e da American Heart Association. Resultados: Quanto à classificação do risco cardiovascular, 54\% da população avaliada apresentou risco potencial e 31\%, moderado. Quanto ao exercício físico praticado 58\% foram considerados inativos, 14\% ativos e 28\% muito ativos. $90 \%$ não receberam orientações profissionais. Conclusão: Os frequentadores do parque público apresentam risco cardiovascular e praticam exercício físico sem orientações individualizadas.

Palavras-chave: Fatores de risco. Doenças cardiovasculares. Atividade física. Caminhada.

\section{Introduction}

Cardiovascular disease (CVD), in particular its presentation as coronary artery disease (CAD) remains the leading cause of death worldwide $(1,2)$ with greater involvement in underdeveloped countries which amounted to approximately $80 \%$ of deaths reported in world population (2).

The Framingham study was among the first to demonstrate that: hypertension, obesity, high cholesterol levels, diabetes mellitus, physical inactivity and smoking are risk factors strongly related to the development of cardiovascular and cerebrovascular diseases(3). This relationship was confirmed by other studies, which added: psychosocial indicator, diet, regular alcohol consumption (2), in addition to genetic predisposition (4).

The increased risk of cardiovascular morbidity and mortality is associated with an increase in sedentary lifestyle (5), since the technological and economic incentives tend to discourage physical activity (6). In contrast, physical activity prevents and reduces the risk of cardiovascular events on $30-50 \%$, it increases serum levels of high density lipoprotein (HDL-C), decreases in low-density lipoprotein (LDLC) and triglycerides, reduces blood pressure, improves blood glucose, insulin resistance, helps in weight loss or maintaining, improves psychological welfare, facilitates smoking cessation, reduces symptoms and mortality after acute myocardial infarction in cardiac patients (7), in addition to reducing the formation and development of atherosclerosis and the incidence of CAD (8). Thus, it promotes and maintains health, reduces the risk of chronic diseases and premature mortality (6). As a result, physical exercise is widely recommended by health professionals (8).

In contrast, vigorous exercise can, acute and transiently increase the risk of acute myocardial infarction (AMI) and sudden death in susceptible individuals. The absolute risk of physical activity related to acute cardiovascular events varies with the prevalence of diagnosis or hidden heart disease and inadequate physical exercise (8), because the risk of AMI in sedentary individuals is six times higher during intense exercise than in that the rest (9).

Thus, especially in people who already have cardiovascular risk, physical exercise should follow recommendations regarding the intensity, duration and frequency of physical activity (10). Population must be informed and made aware of these variables from the practice of regular exercise, like, care about clothing, food, medication and time in order to ensure safe execution so that its benefits are achieved. 
Currently it is noticed great encouragement by the media, health professionals and local government actions that provide places for practicing physical activity and guidance to maintain an active life. Thus, the population is driven, in most cases, to perform exercises before being subjected to a prior cardiovascular evaluation and specific orientation of health professionals.

Thus, these individuals who practice the exercise improperly become more prone to sudden events by increasing their cardiovascular risk (8). Thus, it is essential to do cardiovascular assessment of individuals who attend public squares, to conduct walking and jogging, as well as physical exercise. These actions may generate subsidies to public health services in order to suggest intervention measures to correct the deficiencies found and disseminate the use of this practice optimally and safely, within promotion and health prevention actions, to ensure greater gains, minimizing and slowing the risks related to it.

Thus, the objectives of this study were to identify the cardiovascular risk, namely smoking, alcoholism, high blood pressure, heredity, sedentary lifestyle, stress, obesity, diabetes mellitus, dyslipidemia and physical exercise of the regulars of a municipal public park.

\section{Materials and methods}

Type of research and ethical aspects

This quantitative, cross-sectional and descriptive study followed ethical procedures required by Resolution 466/2012 of the National Health Council, with the approval of the Federal University of Triangulo Mineiro Research Ethics Committee, under number 1666/2010. All subjects read and signed the informed consent form.

\section{Sample}

110 individuals, 60 men (55\%) and 50 women (45\%) aged between $30-77$ years old, with a mean age of $48.8 \pm 11.76$ years old, regulars of a municipal public park were evaluated. This park offers a hiking/race trail, sports fields, skate park and outdoor gym.
Procedures

Initially, individuals were contacted inside the park, at a time when they were performing the exercise, and the research objectives were explained. For those who expressed interest in participating, day and time were scheduled, according to their availability, to perform the evaluations at the same park. They were told to attend fasting for 12 hours and cardiac patients should bring ergometric test.

All evaluations were conducted by physiotherapy instructors and physiotherapy students previously trained through a structured evaluation form based on American College of Sports Medicine (ACSM) and the American Heart Association (AHA) (11) and physical examination. The evaluation form contained identification, followed by a questionnaire on lifestyle habits, cardiovascular risk factors, previous and family diseases and physical activity.

Issues related to physical activity included questions about the presence of cardiovascular symptoms, purpose, type of sport, frequency, duration, orientation existence and evaluation of exercise intensity. Regarding the frequency, duration and intensity of exercise, the subjects were classified according to parameters established by Haskell et al. (6) in inactive, active and very active, according to the recommendations of the ACSM and AHA. This classification characterizes individuals who exercise lasting less than 150 minutes per week in mild to moderate intensity, as inactive; those who practice exercise at moderate intensity for 150 to 300 minutes per week or vigorous intensity 75 to 150 minutes per week as active; and people who exercise for more than 300 minutes a week at moderate intensity or more than 150 minutes in vigorous intensity as very active.

Physical examination consisted of anthropometric measurements, blood pressure and heart rate (HR) at rest measurement, analysis of total cholesterol (TC) and the glycemic index.

Anthropometric measures were taken by the stature and body mass. To measure the height, a stadiometer was used. The subject was instructed to stand upright with head, buttocks and heels and lined up against the stadiometer with the head in the horizontal plane.

For the measurement of body mass, a digital scale (Filizola ${ }^{\circledR}$ ), with a $50 \mathrm{~kg}$ capacity and $50 \mathrm{~g}$ sensitivity was used, in which the individual was instructed to stand barefoot, wearing light clothing. 
Then the body mass index (BMI) was calculated. For classification of nutritional status it was considered as overweight BMI between 25 to $29.9 \mathrm{Kg} / \mathrm{m}^{2}$; obese: BMI greater than or equal to $30 \mathrm{Kg} / \mathrm{m}^{2}$, normal: BMI between 18.5 to $24.9 \mathrm{Kg} / \mathrm{m}^{2}$ and underweight BMI less than $18.4 \mathrm{Kg} / \mathrm{m}^{2}$ (12).

Circumferences of waist and hip were measured with an inelastic tape. The waist/hip ratio (WHR) was determined by dividing the waist circumference (measured at the umbilicus) by hip circumference (level of the femoral trochanters). It was considered that rate higher than 0.8 in women and higher than 0.9 in men are correlated with greater visceral fat distribution, rather than peripheral, ie, increased risk of cardiovascular disease and metabolic syndrome (13).

Blood pressure was measured with an aneroid sphygmomanometer $\left(\mathrm{G}-\mathrm{Tech}^{\circledR}\right)$, only once, after 15 minutes of rest, following the guidelines and classification of the VI Brazilian Guidelines on Hypertension (14).

The assessment regarding the diagnosis of diabetes mellitus was performed through the use of hypoglycemic drugs and the analysis of the glycemic index, using a portable blood glucose monitoring equipment (Accucheck Performa Glucometer of Roche ${ }^{\circledR}$ ), considered as normal random blood glucose greater than $200 \mathrm{mg} / \mathrm{dL}$ (15).

Serum levels of total cholesterol (TC) were recorded by means of a portable biochemical analyzer (Accutrend Plus of Roche ${ }^{\circledR}$ ), in which the measuring principle is based on reflectance photometry method. It was considered a normal standard TC smaller or equal to $200 \mathrm{mg} / \mathrm{d}$ (16).

Based on the data collected, the cardiovascular risk of each participant was classified according to the American Table in: no risk, potential risk, moderate risk and high risk (17).

Based on the data from the questionnaire and physical examination, individualized orientation was given, through pamphlets containing information about the necessary care when practicing physical activity. In addition, guidance was provided on methods of measurement of heart rate in determining the target training zone according to Karvonen formula (18).

Individuals with heart disease diagnosis or who were taking medications that interfere in heart rate received guidance based on exercise tests. Those who already had many risk factors or cardiovascular symptoms were instructed to seek medical attention.

\section{Statistical analysis}

Results are presented descriptively and percentages.

\section{Results}

The sample totaled 110 individuals, 50 (45\%) women and 60 (55\%) men, mean age $49 \pm 12$ years old. Among this population, 18 (16\%) were cardiac patients diagnosed with Chagas disease, heart failure, valvular disease, coronary artery disease, acute myocardial infarction, abnormal heart rhythm and circulatory; $16(14 \%)$ reported having another type of disease and $76(70 \%)$ said they did not have any disease.

Most subjects had more than one cardiovascular risk factor, as shown in Figure 1. With respect to body weight, 29 (26\%) were obese and 51 (46\%) were overweight. Thus, $80(72.7 \%)$ were above the ideal weight range.

In relation to blood glucose levels, three (3\%) had higher than $200 \mathrm{mg} / \mathrm{dL}$ indices. Among them, one had drug treatment for glycemic control and the other two had no diagnosis of diabetes mellitus. In the evaluation of dyslipidemia, measured by analysis of total cholesterol, 33 (30\%) were detected with high values (greater than $200 \mathrm{mg} / \mathrm{dL}$ ) and only 13 (39\%) of these used antilipemics medications.

Based on American Table (17), the sample was rated in accordance with the risk for developing cardiovascular disease, in four groups: no risk, potential risk, moderate risk and high risk (Figure 2).

Moreover, of the 110 individuals evaluated, 22 (20\%) reported being sedentary (not performing regular exercise); 88 (80\%) physical active, all of which practiced walking and $31(28.2 \%)$ associated walking with practices of other activities. However, in applying the classification used by Haskell et al. (6), it was found that 64 (58\%) were inactive, whereas $22(20 \%)$ did not engage in regular physical exercise and 42 (38.2\%) performed regular walks, but did not reach this threshold to be classified as active; 15 (14\%) were active and $31(28 \%)$, very active. When considering only the $18(16 \%)$ cardiac patients, it was observed that 56\% were inactive, $22 \%$ active and $22 \%$ were very active.

When asked about the cardiovascular signs and symptoms present during walking, 18 (16\%) reported dyspnea, pain and tightness in chest, tachycardia and excessive tiredness. Among them, one cardiac patient presented with pain in chest tightness and 
tachycardia. Most individuals 90 (82\%) performed physical exercises in order to improve health conditions and 99 (90\%) had no professional guidelines on how to accomplish them.

\section{Discussion}

In this study, it was noted that $16 \%$ of the study population was cardiac patients and $84 \%$ had risk of developing cardiovascular disease. Other studies point in the same direction, indicating a high incidence of this risk $(19,20)$. Mendonça et al. (9) when assessed cardiovascular risk in active seniors verified the presence of these factors in $70 \%$ of the population.

Among the risk factors observed stood out heredity represented by $61 \%$ of the subjects evaluated, hypertension by $29 \%$, stress by $55 \%$ and obesity by $26 \%$, while the last three are considered modifiable risk factors, and may be reduced through changes in lifestyle.

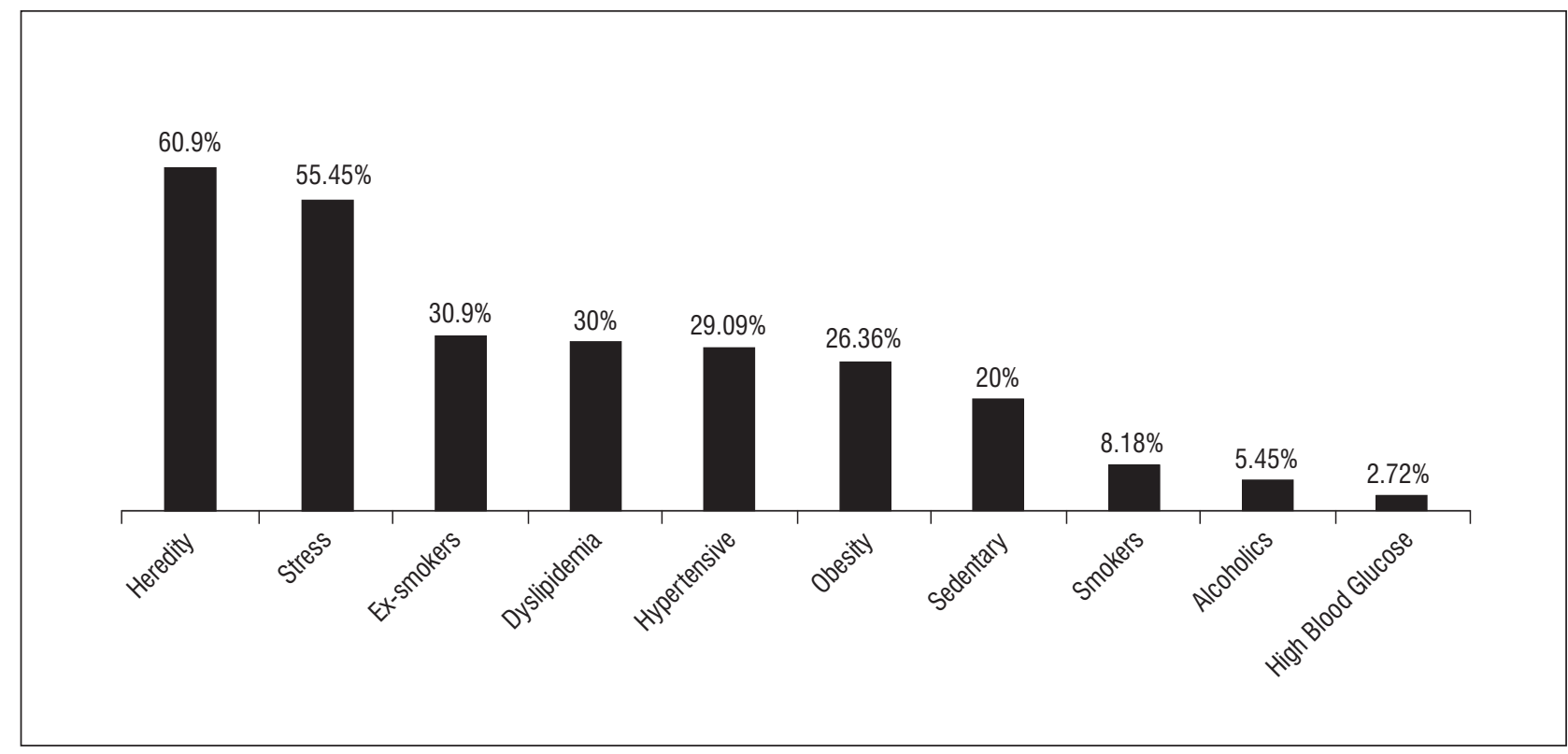

Figure 1 - Cardiovascular risk factors

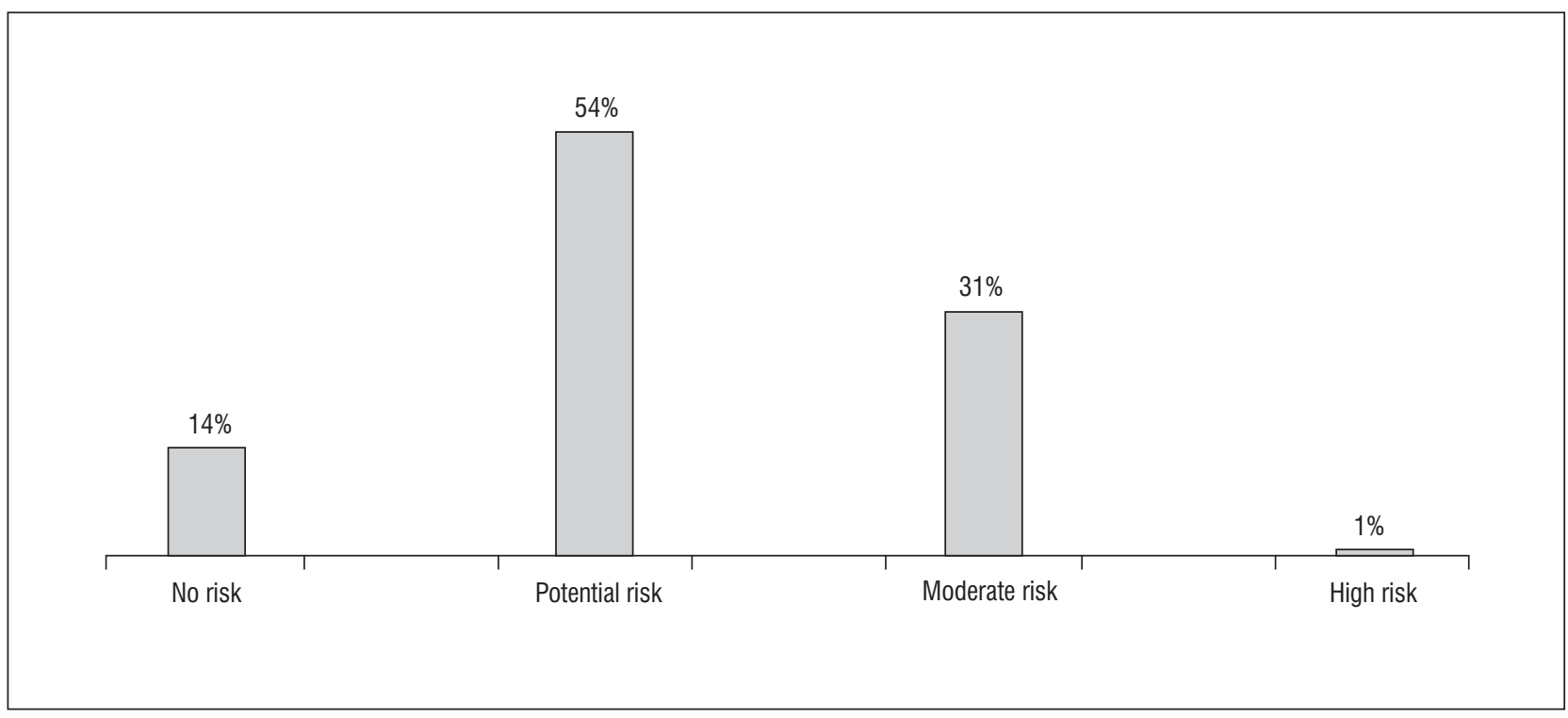

Figure 2 - Cardiovascular risk rating 
It is possible that the percentage of $61 \%$, related to heredity risk factor found in this study is related to the increased incidence and prevalence of cardiovascular disease in the population since the mid-twentieth century, and that continue to prevail especially in underdeveloped countries (2). However, there is disagreement in the literature, as Oliveira et al. (19) compared the cardiovascular risk of active, insufficiently active and inactive regulars of a public park, and found only $28 \%$ of hereditary risk factor. While Coltro et al. (21) evaluated the frequency of cardiovascular risk factors in volunteers who participated in an educational intervention for community health in the city of Botucatu (SP), noting $41 \%$ of hereditary risk factor.

Besides obesity (26\%) it was observed that $46 \%$ of the volunteers were overweight and a further $73 \%$ with high waist/hip ratio, which indicates abdominal obesity.

These results corroborate the study by Matos et al. (20) with employees of Petrobras, most of them sedentary individuals, and $17 \%$ of obese was found, as well as the Forjaz et al. research (22), who evaluated the cardiovascular risk of physically active people, finding $20 \%$ of the obese population.

Further, Zhang et al. (23) reported a higher prevalence of abdominal obesity in the last 15 years, in the American population, which is strongly associated with insulin resistance, dyslipidemia, systemic inflammation, factors that play an essential role in the pathogenesis of cardiovascular disease, metabolic syndrome and certain types of cancer.

A fact that has drawn attention, in the present study was the low prevalence of smokers (8\%) and high ex-smokers (31\%). The World Health Organization reports that one-third of the adult population, about 1.3 billion people, is a smoker. In Brazil, the Ministry of Health shows that $18.8 \%$ of Brazilians are smokers (24). In this context, Carnelosso et al. (25) found the prevalence of cardiovascular risk in the eastern region of Goiânia, and evaluated 3275 volunteers, and $16 \%$ were smokers. While Viebig et al. (26) described the cardiovascular health profile of an adult population in the metropolitan region of São Paulo, where the smoking rate was $22 \%$.

It is possible that the lower prevalence of smokers and most obese, found in this study are due to the fact that the survey had been conducted in a public park walk, which is usually frequented by people interested in improving or maintaining its health. Still, according to Mozaffarian et al. (7), regular physical exercise promotes smoking cessation.

Regarding blood pressure, it was found that 29\% said they are hypertensive. However, 16 people who had declared normotensive presented blood pressure values of hypertension. During physical exercise, elevation of systolic blood pressure and maintaining or reducing diastolic blood pressure occurs (27). Thus, people who already begin exercise with elevated blood pressure levels should be monitoring its blood pressure through supervision and proper exercise prescription, as it is well established in the literature (28), hypertension is the major cause of vascular stroke, highlighting cerebrovascular accident and acute myocardial infarction.

Regarding dyslipidemia, elevated levels of TC in six volunteers (5\%) who used antilipemics medicines was verified, and also elevated levels in another 27 (24\%) who had no knowledge of this fact was verified, revealing that although the majority of the population (82\%) practiced exercise in pursuit for better health, they did not know their real health condition in this sense.

Although $82 \%$ is exercised in pursuit for better health, $90 \%$ did not receive professional guidance on how to accomplish it. Furthermore, $16.3 \%$ had cardiovascular symptoms such as tachycardia, dyspnea disproportionate to exertion and chest pain, suggesting ischemic framework while running the exercise, and may causing an acute cardiac event (29).

Finally, although $80 \%$ of the population does not considered itself sedentary, while applying the classification of Haskell et al. (6) based on the intensity, duration and frequency of weekly exercise performed, it was found that $58 \%$ is considered inactive. Thus, it is possible that this is not reaching the cardiovascular benefits induced by regular physical exercise (7), since they did not perform on the appropriate intensity, duration and frequencies (6). Thus demonstrating the need for better control over the practice of physical exercise through supervised practice or even inserting in cardiac rehabilitation programs, in cases of increased cardiovascular risk.

\section{Conclusion}

It is concluded that public park regulars evaluated in this study have cardiovascular risks and that physical exercises are practiced in a nonspecific 
manner, without previous assessments and individualized guidelines.

Thus, it is relevant to emphasize that in addition to encouraging physical exercise and providing public places to facilitate its practice, it is necessary in the field of public health, greater investment in the proper orientation to the population, carried out by qualified professionals such as physiotherapists and physical educator. This strategy involves significantly little human resources and materials, with potential to reach large segments of the population, with low cost, encouraging autonomy and safety for individuals who exercise, enabling the physical activity to achieve its goals and hence have the greatest positive impact on the population.

\section{References}

1. Guimarães HP, Avezum A, Piegas LS. Epidemiologia do infarto agudo do miocárdio. Rev Soc Cardiol Estado de São Paulo. 2006;16(1):1-7.

2. Gersh BJ, Sliwa K, Mayosi BM, Yusuf S. Novel therapeutic concepts: the epidemic of cardiovascular disease in the developing world: global implications. Eur Heart J. 2010;31(6):642-8.

3. Sytkowsly PA, Kannel WB, D’Agostino RB. Changes in risk factors and the decline in mortality from cardiovascular disease. The Framingham Heart Study. N Engl J Med. 1990;322(23):1635-41.

4. Ignarro LJ, Balestrieri MB, Napoli C. Nutrition, physical activity, and cardiovascular disease: An update. Cardiovasc Res. 2007;73(2):326-40.

5. Kozàkovà M, Palombo C, Morizzo C, Nolan JJ, Konrad T, Balkau B. Effect of sedentary behaviour and vigorous physical activity on segment-specific carotid wall thickness and its progression in a healthy population. Eur Heart J. 2010;31(12):1511-19.

6. Haskell WL, Lee I, Pate RR, Powell KE, Blair SN, Franklin $\mathrm{BA}$, et al. Physical activity and public health: updated recommendation for adults from the American College of Sports Medicine and the American Heart Association. Circulation. 2007;116(9):1081-93.

7. Mozaffarian D, Wilson PWF, Kannel WB. Beyond established and novel risk factors: lifestyle risk factors for cardiovascular disease. Circulation. 2008; 117(23):3031-8.
8. Thompson PD, Franklin BA, Balady GJ, Blair SN, Corrado D, Estes NAM, et al. Exercise and acute cardiovascular events placing the risks into perspective: a scientific statement from the American Heart Association Council on Nutrition, Physical Activity, and Metabolism and the Council on Clinical Cardiology. Circulation. 2007;115(17):2358-68.

9. Mendonça TT, Ito RE, Bartholomeu T, Tinucci T, Forjaz CLM. Risco cardiovascular, aptidão física e prática de atividade física de idosos de um parque de São Paulo. R Bras Ci e Mov. 2004;12(3):57-62.

10. Ciolac EG, Guimarães GV. Exercício físico e síndrome metabólica. Rev Bras Med Esporte. 2004;10(4):319-24.

11. Balady GJ, Chaitman B, Driscoll D, Foster C, Froelicher E, Gordon N, et al. Recommendations for cardiovascular screening, staffing, and emergency policies at health/ fitness facilities. Circulation. 1998;97(22):2283-93.

12. Klein S, Allison DB, Heymsfield SB, Kelley DE, Leibel RL, Nonas C, et al. Waist circumference and cardiometabolic risk: a consensus statement from Shaping America's Health: Association for Weight Management and Obesity Prevention; NAASO, The Obesity Society; the American Society for Nutrition; and the American Diabetes Association. Am J Clin Nutr. 2007;85(5):1197-202.

13. Cavalcanti CBS, Carvalho SCBE, Barros MVG. Indicadores antropométricos de obesidade abdominal: revisão dos artigos indexados na biblioteca Scielo. Rev Bras Cineantropom Desempenho Hum. 2009; 11(2):217-25.

14. Sociedade Brasileira de Cardiologia; Sociedade Brasileira de Hipertensão; Sociedade Brasileira de Nefrologia. VI Diretrizes Brasileiras de Hipertensão. Arq Bras Cardiol. 2010;95(1 supl. 1):1-51

15. American Diabetes Association. Diagnoses and classification of diabetes mellitus. Diabetes Care. 2004; 27(Suppl 1):S5-10.

16. Xavier HT, Izar MC, Faria Neto JR, Assad MH, Rocha VZ, Sposito AC, et al. V Diretriz Brasileira de Dislipidemias e Prevenção da Aterosclerose. Arq Bras Cardiol. 2013;101(4 supl. 1):1-20.

17. Mion Junior D, Nobre F. Risco Cardiovascular Global. São Paulo: Lemos Editorial; 1999. 
18. Karvonen MJ, Kentala E, Mustala O. The effects of training on heart rate; a longitudinal study. Ann Med Exp Biol Fenn. 1957;35(3):307-15.

19. Oliveira GF, Bartholomeu T, Tinucci T, Forjaz CLM. Risco cardiovascular de usuários ativos, insuficientemente ativos e inativos de parques públicos. Rev Bras Cineantropom Desempenho Hum. 2008;10(2):170-5.

20. Matos MFD, Silva NAS, Pimenta AJM, Cunha AJLA. Prevalência dos fatores de risco para a doença cardiovascular em funcionários do centro de pesquisas da Petrobras. Arq Bras Cardiol. 2004;82(1):1-4.

21. Coltro RS, Mizutani BM, Mutti A, Délia MPB, Martinelli LMB, Cogni AL, et al. Frequency of cardiovascular risk factors in volunteers attending a community-based health education intervention. Rev Assoc Med Bras. 2009;55(5):556-62.

22. Forjaz CLM, Tinucci T, Bartholomeu T, Fernandes TEM, Casagrande V, Massucato JG. Avaliação do risco cardiovascular e da atividade física dos frequentadores de um parque da cidade de São Paulo. Arq Bras Cardiol. 2002;79(1):35-42.

23. Zhang C, Rexrode KM, van Dam RM, Li TY, Hu FB. Abdominal obesity and the risk of all-cause, cardiovascular, and cancer mortality: sixteen years of follow-up in US women. Circulation. 2008;117(13):1658-67.

24. Brasil. Ministério da Saúde. Portal da Saúde [website]. 2010 [cited 2010 Nov 11]. Available from: http://portal.saude.gov.br

25. Carnelosso ML, Barbosa MA, Porto CC, Silva SA, Carvalho MM, Oliveira ALI. Prevalência de fatores de risco para doenças cardiovasculares na região leste de Goiânia(G0). Ciênc. Saúde Coletiva. 2010;15 (Supl. 1):1073-80.
26. Viebig RF, Valero MP, Araújo F, Yamada AT, Mansur AJ. Perfil de saúde cardiovascular de uma população adulta da região metropolitana de São Paulo. Arq Bras Cardiol. 2006;86(5):353-60.

27. Brum PC, Forjaz CLM, Tinucci T, Negrão CE. Adaptações agudas e crônicas do exercício físico no sistema cardiovascular. Rev Paul Educ Fís. 2004;18 (n. esp.):21-31.

28. Castro JAB, Epstein MG, Sabino GB, Nogueira GLO, Blankenburg C, Staszko KF, et al. Estudo dos principais fatores de risco para acidente vascular encefálico. Rev Bras Clin Med. 2009;7:171-3.

29. Santos ES, Minuzzo L, Pereira MP, Castillo MTC, Palácio MAG, Ramos RF, et al. Registro de síndrome coronariana aguda em um centro de emergência em cardiologia. Arq Bras Cardiol. 2006;87(5):597-602.

Received: $11 / 10 / 2013$

Recebido: 10/11/2013

Approved: 06/21/2014

Aprovado: 21/06/2014 